\author{
${ }^{1}$ ДУ «Національний науковий центр «Інститут кардіології імені академіка М.Д. Стражеска» НАМН України», Київ
}

${ }^{2}$ Національна медична академія післядипломної освіти імені П.Л. Шупика, Київ

${ }^{3}$ КНП «Бучанський центр первинної медико-санітарної допомоги»

\title{
Медико-соціальне обґрунтування алгоритму ранньої діагностики та профілактики психосоматичних порушень на рівні первинної медичної допомоги *
}

Мета - розробити новий алгоритм медичної допомоги пацієнтам з урахуванням визначених факторів ризику, що мають вплив на появу та розвиток розладів психіки і поведінки в умовах впровадження сімейної медицини. Об'єкт дослідження. При розробці та медико-соціальному обгрунтуванні нового алгоритму ранньої діагностики і профілактики психосоматичних порушень на первинній ланці ми користувались отриманими даними при проведенні власних досліджень, результатами проведеного аналізу законодавчої бази стосовно організації системи охорони здоров'я та ї̈ трансформації на засадах сімейної медицини, достовірною інформацією опрацьованої наукової літератури. Діагностику основних показників впливу стресу - тривоги та депресії - здійснено за допомогою загальновживаних методик, адаптованих до дослідження. Результати. Саме пацієнтє основним суб'єктом відповідальності за власне здоров'я шляхом дотримання здорового способу життя. Сучасна система охорони здоров'я недостатньо спрямована на профілактику захворювань та їх раннє виявлення, що призводить до розвитку хронічної форми хвороб, підвищення первинної інвалідизації та смертності, яким можна запобігти. Висновки. Розроблено новий алгоритм медичної допомоги в умовах впливу стресу з урахуванням ранньої діагностики, лікування, реабілітації та індивідуальної профілактики порушень психічного здоров'я у осіб із соматичними захворюваннями в межах запровадженого державою реформування системи охорони здоров'я та в умовах розвитку сімейної медицини.

Ключові слова: алгоритм, розлади психіки та поведінки, фактори ризику, психосоматичні порушення, стрес.

\section{Вступ}

Держава створює умови для ефективного та доступного для всіх громадян медичного обслуговування (Верховна Рада України, 1996). Доступність та якість медичної допомоги населенню гарантується Конституцією України, і це є одним зі стратегічних напрямків розвитку держави щодо формування оновленої моделі охорони здоров'я на рівні первинної медичної допомоги, побудованої на засадах сімейної медицини. Справедливий розподіл, раціональне використання основних ресурсів (кадри, фінанси та матеріально-технічна база) - найважливіші інструменти ефективного управління.

Виходячи з документів провідних міжнародних організацій (Організація Об'єднаних Націй, Всесвітня організація охорони здоров'я (ВОО3), Організація економічного співробітництва та розвитку тощо), саме в XXI ст. здоров'я людини розглядається як інтеграл розвитку та добробуту суспільства та один із головних макроекономічних факторів, вагомий компонент сталості соціально-економічного розвитку (Білинська М.М., Радиш Я.Ф. (ред.), 2013).

В Україні недостатня дієва та результативна система скринінгу, раннього виявлення тадіагностики як ефективного інструментаіндикатора профілактики захворюваності та поширеності розладів психіки і поведінки. Актуальність цієї проблеми виокремлено та відзначено BOO3 (World Health Organization, World Organization of Family Doctors, 2008; World Health Organization, 2014).

Понад 20\% дорослих мають психічні розлади, найпоширеніший з яких - депресія - одне з розповсюджених захворювань як у психіатричній, так і у соматичній практиці. У популяційних дослідженнях депресію виявляють у 3-6\% населення, близько у $1 \%$ щороку діагностують первинно. Вивчаючи матеріали Національного інституту психічного здоров'я США (National Institutes

*Робота є фрагментом науково-дослідницької роботи «Медико-соціальне обгрунтування моделі оптимізації первинної медичної допомоги в умовах стресу» (номер державно реєстрації теми № 0118U100198). of Health - NIH) та ВОО3, стало відомо, що 18-25\% жіночого населення та 7-12\% чоловічого - щонайменше один раз пережили дію стресового чинника і, як наслідок, депресивний епізод, у близько 70\% відзначають рецидиви, а 15\% випадків закінчуються суїцидом (Симаненков В.И. и соавт., 2008; Байбарак Н.А., 2015). Це свідчить, що якою би значною не була економічна складова для суспільства, поліпшення якості та ефективності самого лікувально-діагностичного процесу на первинній ланці безпосередньо залежить від своєчасної профілактики, діагностики та лікування.

Мета - розробити новий алгоритм медичної допомоги пацієнтам з урахуванням визначених факторів ризику, що мають вплив на появу та розвиток розладів психіки і поведінки в межах запровадженого державою реформування системи охорони здоров'я та в умовах розвитку сімейної медицини.

\section{0б'єкт і методи дослідження}

При розробці та медико-соціальному обґрунтуванні оптимізованого алгоритму ранньої діагностики та профілактики психосоматичних порушень на первинній ланці користувалися даними, отриманими при проведенні власних досліджень, результатами аналізу законодавчої бази стосовно організації системи охорони здоров'я та її трансформації на засадах сімейної медицини, достовірною інформацією опрацьованої наукової літератури і світового досвіду.

Діагностування основних показників впливу стресу - тривоги та депресії - виконано за допомогою загальновживаних методик, адаптованих до дослідження.

Оцінку стану психічного здоров'я, його вплив на соматичні прояви виявляли за допомогою простого тадоступного якдля пацієнтів, так і для лікарів скринінгу порушень психіки та поведінки. Стислість, інформативність, легкість в опрацюванні та можливість здійснення моніторингу в часіє оптимальними індикаторами опитувальника, що $€$ тактичним кроком у профілактиці та ранньому виявленні психосоматичних захворювань і запобіганні їх ускладненням. 


\section{Результати та їх обговорення}

Аналізуючи рівень здоров'я населення міста Буча Київської області та України, встановлено тенденцію щодо зростання смертностіпорівняно з 2012 р. на 3,79\% (з 13,2 до 13,7 з розрахункуна 1000 населення), а також поширеності та захворюваності. За підсумками 2016 р. найвища захворюваність в області (11365,8 на 10 тис. населення) у 1,76 раза перевищує загальноукраїнський рівень.

Щодо поширеності розладів психіки та поведінки в Київській області протягом 5-річного періоду виявлено, що у місті Буча також простежується зростання у 2016 р. на 7,33\% відносно 2015 р. (450,9 на 10 тис. населення), так і проти 2012 р. на 24,59\% $(361,9)$, а показники захворюваності одні з найвищих $-72,5$ на 10 тис. населення. Ці синдроми виникали й були частими серед осіб з підвищеним рівнем депресії, агресії та тривоги. Це є медико-соціальною проблемою, яка потребує тактичного рішення на рівні держави (Blank L. et al., 2007; World Health Organization, 2010). Незважаючи на проведення заходів з метою зниження тривожно-депресивних розладів, поширеність і захворюваність не знижуються.

До хронічних станів відносять психічні розлади, які мають вплив на інші захворювання, такі як серцево-судинні, ВІЛ-інфекція/ СНІД, рак, ендокринні, і відчувають їх зворотній вплив і такі, що потребують загальних заходів та зусиль щодо поєднання і мобілізації всіх ресурсів. За даними ВООЗ, депресія призводить до інфаркту міокарда та цукрового діабету, а обидва ці стани підвищують імовірність депресії. Багато факторів ризику, такі як низький рівень фізичної активності та соціально-економічний статус, тютюнопаління, вживання алкоголю і стрес, діють як у разі хронічних захворювань, так і психічних розладів (Всемирная организация здравоохранения, 2012).

Встановлено, що за відсутності соматичних захворювань частота виявлення депресії $€$ найнижчою та становить 14 (29,2\%) випадків, а їх наявність підвищує ризик формування стресового статусу і розвитку депресії, при цьому $\geqslant 2$ діагнозів (поєднаної патології) характерно для більшості - $423(79,5)$, і саме при коморбідності частоту депресії реєструють у $218(51,5 \%)$ хворих ризик розвитку зростає у 2,58 раза (відносний ризик (ВР) 2,58, 95\% довірчий інтервал (ДІ) 1,35-4,95; p=0,003).

Тривогу виявляють дещо рідше, ніж депресію - у 176 $(33,1 \%)$ хворих, діагностують за допомогою модифікованих на базі відомих вірогідно обгрунтованих анкет іхарактеризують сам рівень психічного здоров'я, а також його вплив на клініку соматичних проявів. За відсутності соматичних захворювань частота виявлення тривоги становить 8 (16,7\%) випадків. Наявність соматичних захворювань підвищує ризик формування тривожного статусу пацієнтів як індикатора стресового стану. Приріст частоти тривоги характерний для всіх соматичних захворювань. Наявність $\geqslant 2$ діагнозів супроводжується приростом частоти розвитку тривоги у 2,79 раза (ВР 2,79, 95\% ДІ 1,27-6,09; $p=0,008$ ). У пацієнтів з інвалідністю ВР тривоги становить 3,60 (95\% ДІ 1,91-6,81; $\mathrm{p}=0,0001)$.

Усі фактори ризику, які впливають на структуру стресової події та захворюваність, у тому числі на розлади психіки та поведінки, розділено на спадкові, медико-демографічні, екологічні, соціально-економічні, особистісні, умови праці, поведінкові та організаційні (Всемирная организация здравоохранения, 2012).

Нами встановлено, що серед усіх респондентів показник по-

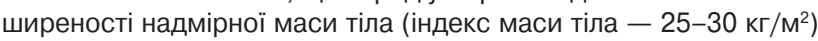
становив $19,5 \pm 1,7 \%$, ожиріння різного ступеня (індекс маси тіла $\left.>30 \mathrm{\kappa г} / \mathrm{M}^{2}\right)-30,1 \pm 2,0 \%$. Відсутність регулярної фізичної активності з метою оздоровлення виявляли у $433(81,4 \%)$ осіб, проте надмірні фізичні навантаження, в тому числі на робочому місці, у 280 (52,6\%) осіб. Характер харчування хворих, який, вірогідно, зумовлений матеріальним станом сім'ї, оцінювали за частотою вживання риби, овочів та фруктів. Регулярне вживання фруктів (щоденно, чи не рідше 3 разів на тиждень) становило 18 (21,7\%), епізодичне - 158 (35,2\%) осіб. Аналогічну закономірність відзначено щодо вживання риби: регулярно вживають - 16 (18,0\%), не вживають чи дуже рідко вживають -160 (36,1\%). Вживання тютюнових виробів відзначали лише 93 (17,5\%) пацієнтів, алкоголю з епізодичністю кілька разів на місяць - 142 (26,7\%), кілька разів на рік - 210 (39,5\%) осіб. Виявлено, що 144 (27,1\%) респондентів незадоволені низьким рівнем санітарно-технічних умов праці, а психологічними умовами роботи - 183 (34,4\%).
Згідно з оцінкою даних дослідження за шкалою HADS (Hospital Anxiety and Depression Scale), у 290 (54,5\%) хворих наявні прояви стресового стану, що проявляється у наявності депресії (252), тривоги (176) чи їх комбінації; у 242 (45,5\%) хворих цих ознак не відзначено. Тобто перенесений стрес та його хронізація мають негативний вплив на розвиток та ускладнений перебіг хвороби, а причини та/чи їх мінімізація визначають ефективність медичної допомоги.

Визначення факторів ризику виникнення і розвитку порушень психіки та поведінки здійснюється за розробленим алгоритмом (рис. 1). Спочатку, слідуючи нашому алгоритму, першочергово проводимо скринінг чинників негативного впливу, користуючись інструментами дослідження (анкетами). При виявленні порушень психіки та необхідності втручання відповідного фахівця на догоспітальному рівні для надання амбулаторної допомоги, лікар загальної практики - сімейної медицини (ЗПСМ) направляє пацієнта на консультацію до вузькопрофільного фахівця (медичного психолога, психотерапевта), в іншому разі (наявність психічних порушень клінічного рівня) пацієнта направляють до спеціалізованого (стаціонарного) закладу охорони здоров'я.

Виявлення негативних чинників впливу передбачає розробку спеціальної програми на індивідуальному рівні та обов'язкові заходи здорового способу життя (ЗСЖ) як індикатори щодо зменшення вираженості цих факторів. Відсутність факторів впливу передбачає загальну консультацію лікаря ЗПСМ щодо дотримання основних принципів ЗСЖ.

Побудова та організація ЗСЖ може мати розвиток на різних рівнях людського буття - популяційному, груповому, родинному та індивідуальному. Зміна поведінки в цільових групах необов'язково виникатиме на тому самому рівні, на який здійснюємо вплив. Вплив на популяційному рівні проявлятиметься в тому числі через індивідуальний, вплив на родинному рівні матиме результат на груповому тощо (Голованова І.А. та співавт., 2016).

Саме для подолання зазначених основних факторів ризику, які мають вплив на спричинення появи та розвитку розладів психіки і поведінки власне й побудовано нашу функціональноорганізаційну структуру профілактики на індивідуальному, груповому (родинному) та популяційному (національному) рівнях (рис. 2).

Отже, охорона здоров'я є досить складною системою з багатьма чинниками та детермінантами здоров'я, які охоплюють все суспільство (Кабінет Міністрів України, 2011), а здоров'я нації державний пріоритет у побудові цих взаємовідносин.

Успішна реалізація заходів щодо пропаганди ЗСЖ можлива в суспільстві з якісними законами, які спрямовані на нормативноправове врегулювання ЗСЖ, його впровадження на інституційних рівнях.

Інституційна взаємодія під час реформування вимагає кардинальних та системних заходів при створенні системи, орієнтованої на пацієнта, здатної забезпечити медичну допомогу для всіх громадян на рівні розвинутих Європейських держав, а саме пацієнт € основним суб'єктом відповідальності за власне здоров'я, через дотримання ЗСЖ (Указ Президент України, 2015).

Як Концепція Загальнодержавної програми «Здоров'я-2020: український вимір», так і Концепція розвитку охорони психічного здоров'я в Україні на період до 2030 р. виокремлюють шляхи подолання проблем:

- розроблення і впровадження новітніх технологій мінімізації факторів (чинників) ризику захворювань і створення сприятливого для здоров'я середовища на основі даних наукових досліджень;

- розроблення стратегії з питань формування усвідомленого та відповідального ставлення до власного здоров'я та особистої безпеки;

- підвищення якості кадрового забезпечення та рівня професійної підготовки фахівців із питань профілактики та раннього виявлення хвороб;

- проведення сучасних інноваційних наукових розробок з обов'язковим створенням ефективної системи їх впровадження у практику охорони здоров'я (взаємодія зі зворотним зв'язком); 


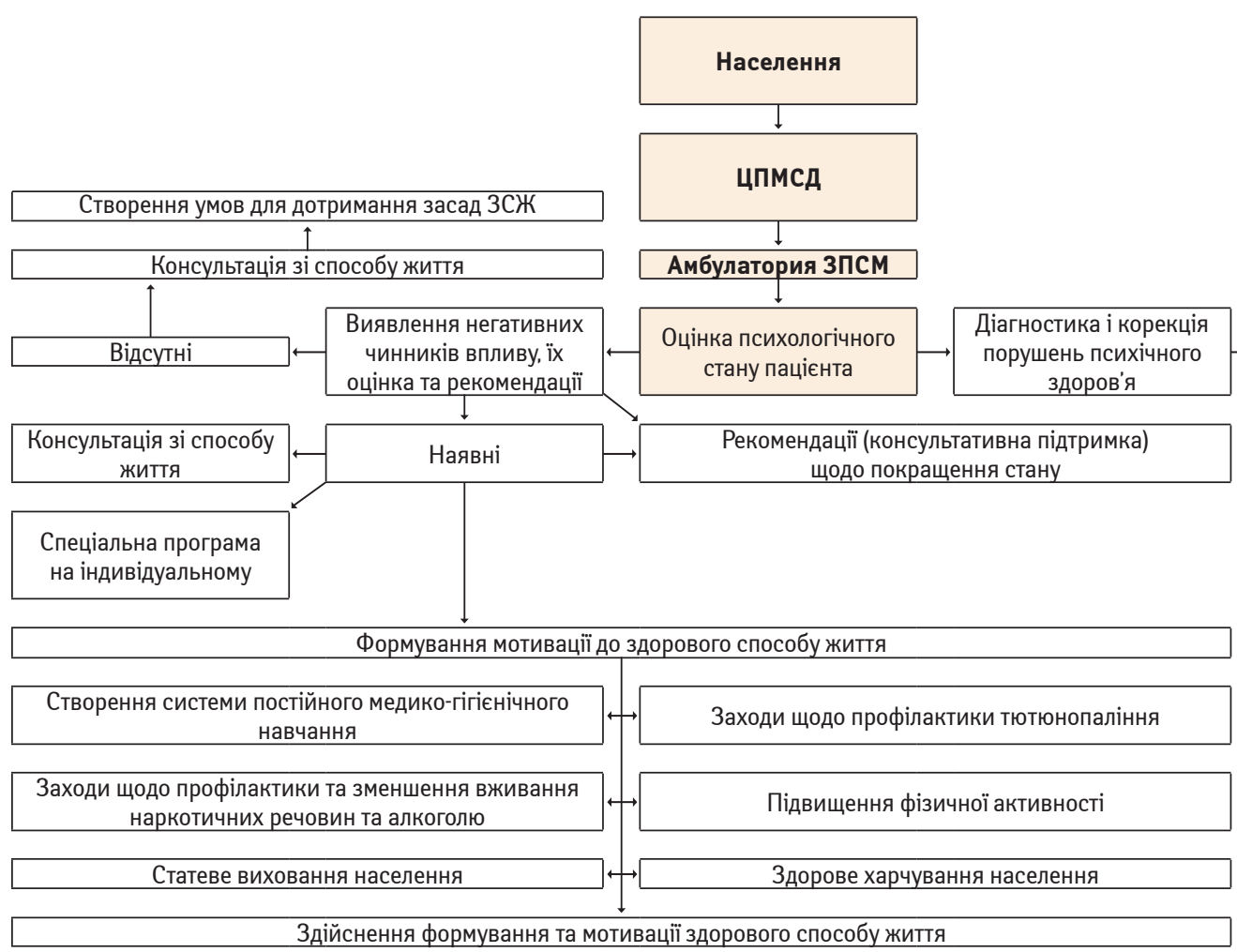

\begin{tabular}{|c|}
\hline $\begin{array}{c}\text { Регулярне відвідування } \\
\text { лікуючого лікаря } \\
\text { (мінімально } 2 \text { рази на рік) }\end{array}$ \\
\hline $\begin{array}{c}\text { Лікування в межах } \\
\text { спеціалізованого закладу } \\
\text { психічного здоров'я }\end{array}$ \\
\hline$\uparrow$ \\
\hline Клінічний рівень \\
\hline$\uparrow$ \\
\hline Розширена діагностика \\
порушень, консультативна \\
підтримка \\
\hline
\end{tabular}

Субклінічний рівень

\begin{tabular}{c}
$\downarrow$ \\
\hline Лікування в межах \\
лікувального закладу \\
первинної ланки \\
\hline
\end{tabular}
(1)

Регулярне відвідування лікуючого лікаря (мінімально 2 рази на рік)

Рис. 1. Алгоритм медичної допомоги пацієнтам за наявності чи відсутності факторів ризику

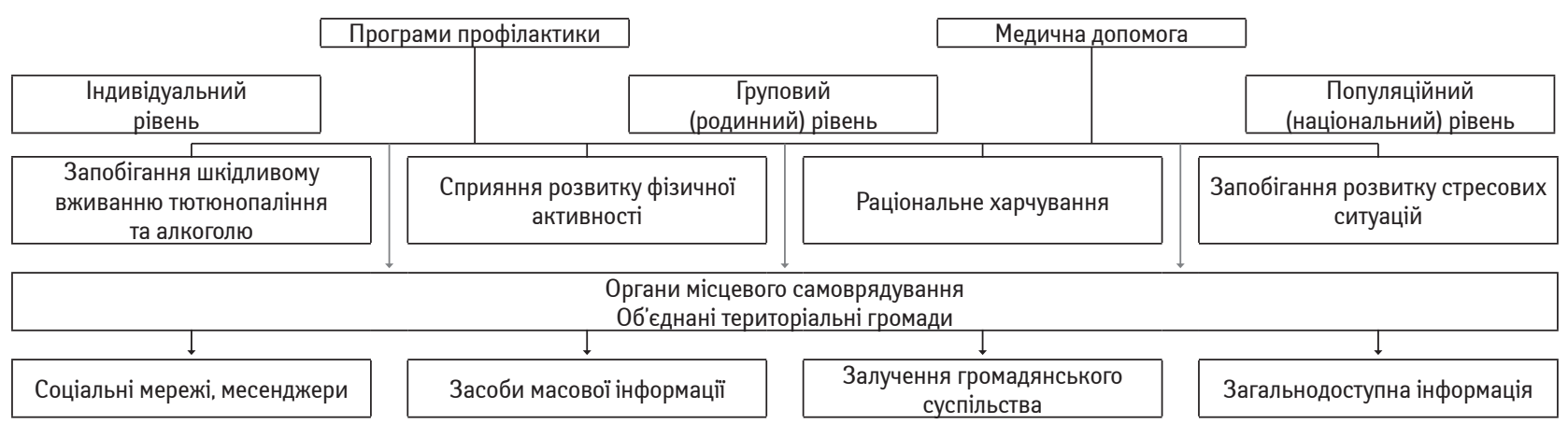

Рис. 2. Функціонально-організаційна структура профілактики розладів психіки та поведінки на первинному рівні в межах індивідуального, родинного та популяційного рівнів

- проведення наукових досліджень зі збереження та зміцнення здоров'я шляхом формування громадської системи охорони здоров'я, первинної профілактики захворювань та вивчення негативного впливу факторів ризику і соціальних детермінант на здоров'я та шляхів його мінімізації.

Відповідно до Європейської стратегії «Здоров'я-2020», вагомими факторами ризику, на зменшення яких мають бути спрямовані загальні зусилля, визнано тютюн, зловживання алкоголем, неналежна фізична активність, нездорове харчування (World Health Organization, 2013). Ще одним не менш вагомим фактором є самі стресові ситуації, які виникають внаслідок військової агресії на Сході України. Підтримання психічногоздоров'япостраждалихвнаслідок збройного конфлікту стало індикатором проблем в системі охорони здоров'я при наданні психологічної допомоги (Устінов О.В., 2017).

У державі впроваджується Стратегія сталого розвитку «Україна-2020", завдяки якій передбачено застосування алгоритму дій щодо забезпечення доступу осіб до системи охорони здоров'я відповідно до програми Європейського Союзу «Європейська стратегія здоров'я-2020». Ефективна взаємодія на всіх рівнях медичної допомоги можлива за умови побудови якісно нової інституції, здатної відповідати викликам суспільства (Устінов О.В., 2017). Для вирішення проблемних питань у сфері психічного здоров'я, а саме його охорони та збереження, необхідні міжгалузева взаємодія та узгоджені заходи фахівців та суб'єктів громадянського суспільства (Указ Президента України, 2015).
Станом на сьогодні Міністерством охорони здоров'я України проводиться робота щодо підготовки Національного плану заходів з охорони психічного здоров'я на період до 2030 р., а також створення Державної установи «Центр психічного здоров'я МО3 україни».

Впровадження 3СЖ здійснюється через регіональні та місцеві програми шляхом посилення заходів щодо запобігання тютюнопалінню та шкідливому вживанню алкоголю, залучення населення до фізичної (рухової) активності, перш за все дітей та молоді, пропагування здорового та раціонального харчування, запобігання впливу чи мінімізації стресових ситуацій (Голованова І.А. та співавт., 2016).

Дотримання населенням ЗСЖ для збереження та зміцнення здоров'я у п'ять разів ефективніше, ніж лікувально-діагностичні процедури. За інформацією ВООЗ, співвідношення витрат і прибутків від виконання програм ЗСЖ становить 1 до 8 (Указ Президента України, 2016). Побудова системи профілактичних заходів щодо запобігання хворобам та формування активного громадянського суспільства - складова реформи системи охорони здоров'я на первинній ланці, де головну роль буде виконувати лікар ЗПСМ. Системний підхід впровадження заходів ЗСЖ на всіх рівнях потребує усвідомлення у громадян думки щодо важливості ЗСЖ. Популяризація та доступність ведення ЗСЖ через призму впливу на свідомість людини є ознакою довіри пацієнта. 


\section{Висновки}

Розроблено новий алгоритм медичної допомоги в умовах впливу стресу з урахуванням ранньої діагностики, лікування, реабілітації та індивідуальної профілактики порушень психічного здоров'я у пацієнтів із соматичними захворюваннями в межах запровадженого державою реформування системи охорони здоров'я та в умовах розвитку сімейної медицини. Посилення заходів на етапі надання первинної медичної допомоги щодо запобігання чи мінімізації впливу чинників ризику через формування базису ЗСЖ на індивідуальному, груповому (родинному) та популяційному (національному) рівнях.

\section{Список використаної літератури}

Байбарак Н.А. (2015) Клініко-типологічний підхід до прогнозування особливостей перебігу рекурентного депресивного розладу (http://journals.uran. ua/sciencerise/article/view/57235).

Білинська М.М., Радиш Я.Ф. (ред.) (2013) Державна політика у сфері охорони здоров'я (http://academy.gov.ua/NMKD/library_nadu/Monogr/457d99ffa477-4205-baaf-2cee246fe3da.pdf).

Верховна Рада України (1996) Конституція України (http://zakon5.rada. gov.ua/laws/show/254k/96-вp).

Всемирная организация здравоохранения (2012) Нулевая версия проекта Глобального плана действий по охране психического здоровья 2013-2020 (https://psychiatr.ru/download/542?view=1\&name=Global+MNH+Act ion+Plan+0slo+RUS.pdf).

Голованова І.А., Лисак В.П., Закрутько Л.І., Хорош М. В. (2016) Науково-методичні підходи до модернізації способу життя людей, що мають фактори ризику артеріальної гіпертензії (методичні рекомендації) (http://elib.umsa.edu.ua/ jspui/bitstream/umsa/3991/1/MR_Nauk_metod_podx_k_modern_sp_zhizni.pdf).

Кабінет Міністрів України (2011) Розпорядження Кабінету Міністрів України від 31.10.2011 р. № 1164-р «Про схвалення Концепції Загальнодержавної програми «Здоров'я 2020: український вимір» (http://zakon2.rada.gov. ua/laws/show/1164-2011-p?test=4/UMfPEGznhhgly.Zig080vMHI4w2s80msh8le6)

Симаненков В.И., Винокур В.А., Гриневич В.Б. (2008) Психосоматические расстройства в практике терапевта (руководство для врачей). СанктПетербург, 335 с

Указ Президента України (2015) Указ Президента України від 12.01.2015 р. № 5/2015 «Про Стратегію сталого розвитку «Україна - 2020» (http://zakon4.rada.gov.ua/laws/show/5/2015).

Указ Президента України (2016) Указ Президента України від 09.02.2016 р. № 42/2016 «Про Національну стратегію з оздоровчої рухової активності в Україні на період до 2025 року «Рухова активність - здоровий спосіб життя - здорова нація» (http://zakon.rada.gov.ua/laws/show/42/2016).

Устінов О.В. (2017) В Україні буде створено Центр психічного здоров'я. Укр. мед. часопис (https://www.umj.com.ua/article/106792).

Blank L., Grimsley M., Goyder E. et al. (2007) Community-based lifestyle interventions: changing behaviour and improving health. J. Public Health (Oxf.), 29(3): $236-245$.

World Health Organization (2010) mhGAP Intervention Guide for mental, neurological and substance use disorders in non-specialized health settings (http:// www.who.int/mental health/publications/mhGAP intervention guide/en/\#).

World Health Organization (2013) Global action plan for the prevention and control of noncommunicable diseases 2013-2020. Geneva, $103 \mathrm{p}$.

World Health Organization (2014) Realizing our vision: report of the Regional Director on the work of WHO in the European Region in 2012-2013. Copenhagen, $67 \mathrm{p}$.

World Health Organization, World Organization of Family Doctors (2008) Integrating mental health into primary care: a global perspective, WHO, Geneva, $206 \mathrm{p}$.

\section{Медико-социальное обоснование алгоритма ранней диагностики и профилактики психосоматических нарушений на уровне первичной медицинской помощи \\ В.М. Корнацкий, В.М. Михальчук, Л.А. Дяченко}

Резюме. Цель - разработать новый алгоритм медицинской помощи пациентам с учетом определенных факторов риска, влияю- щих на появление и развитие расстройств психики и поведения в условиях внедрения семейной медицины. Объект исследования. При разработке и медико-социальном обосновании нового алгоритма ранней диагностики и профилактики психосоматических нарушений на уровне первичного звена использованы данные, полученные при проведении собственных исследований, результаты проведенного анализа законодательной базы по организации системы здравоохранения и ее трансформации на принципах семейной медицины, достоверная информация научной литературы. Диагностика основных показателей воздействия стресса тревоги и депрессии - выполнена с помощью общеупотребительных методик, адаптированных к исследованию. Результаты. Именно пациент является основным субъектом ответственности за собственное здоровье, за соблюдение здорового образа жизни. Современная система здравоохранения недостаточно направлена на профилактику заболеваний и их раннее выявление, что приводит к возникновению хронической формы болезней, росту первичной инвалидизации и смертности, которые можно предотвратить. Выводы. Разработан новый алгоритм медицинской помощи в условиях воздействия стресса с учетом ранней диагностики, лечения, реабилитации и индивидуальной профилактики нарушений психического здоровья у больных с соматическими заболеваниями в рамках введенного государством реформирования системы здравоохранения и в условиях развития семейной медицины

Ключевые слова: алгоритм, нарушение психики и поведения, факторы риска, психосоматические нарушения, стресс.

\section{Medical and social rationale of the algorithm of early diagnostics and prevention of psychosomatic disorders at primary care \\ V.M. Kornatsky, V.M. Mikhalchuk, L.O. Diachenko}

Summary. Aim - to develop a new algorithm of medical care in patients taking into account the identified risk factors that have an impact on promoting the emergence and development of mental disorders and behavior in the context of the introduction of family medicine. Object of study. In the development and medical and social substantiation of a new algorithm for early diagnosis and prevention of psychosomatic disorders in the primary care, we used the data obtained during our own research, the results of the analysis of the legislative framework on the organization of the health care system and its transformation on the basis of family medicine, reliable information elaborated scientific literature. Diagnosis of the main indicators of stress - anxiety and depression - was performed using commonly used methods adapted to the study. Results. The patient is the main subject of responsibility for his or her own health through the observance of healthy lifestyle. The modern health system is not sufficiently focused on disease prevention and early detection, which leads to the emergence of chronic forms of illness, the growth of primary disability and mortality that can be prevented. Conclusions. A new algorithm of medical care under conditions of stress has been developed taking into account early diagnosis, treatment, rehabilitation and individual prevention of mental health disorders in patients with somatic diseases within the framework of implemented reformation of the state health care system and in the conditions of the development of family medicine.

Key words: algorithm, psychological disorder, behavior disorder, risk factors, psychosomatic disorders, stress.

\section{Адреса для листування:}

Дяченко Леся Олександрівна

08292, Буча, вул. Б. Хмельницького, 2

Комунальне некомерційне підприємство

«Бучанський центр первинної медико-санітарної допомоги

E-mail: 0674080695L@gmail.com

Одержано 11.02.2019 